\title{
KREEKA PÄRISNIMED ANTIIKKIRJANDUSE ÕPIKUTES BALTIMAADE NÄITEL
}

\author{
LİVA BODNIECE, AUDRONE் KUČINSKIENÉ, \\ MARIA-KRISTIINA LOTMAN
}

$\mathrm{K}$ uigi viimasel ajal on palju räägitud tõlkeloo kaardistamise ja uurimise tähtsusest, on vähem tähelepanu pööratud vajadusele seda teha ka komparatiivsest perspektiivist, kõrvutades erinevaid traditsioone: just nii võivad välja tulla olulised jooned ja seaduspärasused, mis muidu jääksid märkamatuks. Sellisel lähenemisel on praktilised eelised, kuivõrd see aitab põhjalikumalt, täpsemalt ja senisest avarama vaatega analüüsida tõlkelugu, tõlkenorme ja valitsevaid strateegiaid, ent sel on ka teoreetilised väärtused nt tüpoloogilisest, evolutsioonilisest, kontseptuaalsest vaatevinklist.

Lisaks kõige kesksematele küsimustele, nagu kes, mida ja kuidas tõlkis, on tõlkeloo uurimisel oluline pöörata tähelepanu ka kitsamatele probleemidele, sh sõnamängude, terminite, reaalide, aga samuti pärisnimede vahendamisele. Pärisnimed on sageli rohkem kui lihtsalt ortograafiliste normide peegeldajad - nad võivad olla ka ajastumärgid, peegeldades valitsevaid kultuurilisi ja ideoloogilisi suundumusi, ning ka need suundumused võib reljeefsemalt esile tuua just komparatiivne analüüs.

Pärisnimede tõlkimisel võib laias laastus eristada kahte vastandlikku lähenemist: võõrapärastavat ja kodustavat tõlkeviisi. ${ }^{1}$ Võõrapärastavas tõlkes esitatakse nimekujud võimalikult originaalilähedaselt, kodustavas tõlkes aga tehakse nimi sihtkultuurile omaseks, kas nimekuju sihttraditsioonile kohandades või asendades tähendusega nime lausa sihtkeelse tõlkevastega (nt Scipio Africanuse asemel Scipio Aafriklane või Hypnos kui Uni ja Thanatos kui Surm). Ent isegi kui valitakse võorrapärastav meetod, andes nimed edasi sellisel kujul, nagu need lähtekultuuris on, teise alfabeedi korral vaid transkribeerituna, näitab praktika, et sellel lähenemisel on rohkem nüansse. Näiteks võib nime tüvi olla edasi antud originaali järgides, ent morfoloogiline lõpp olla ära jäetud või muudetud. Samuti võib esineda variatsioone transkriptsioonireeglites, mille tagajärjel võib üks ja sama nimi küll olla täpselt transkribeeritud, aga välja näha sootuks erinev.

Käesoleva artikli eesmärgiks on vaadelda võrdlevalt antiiknimede vahendamise lugu kolmes sarnase saatusega riigis - Lätis, Leedus ja Eestis. Väga suure materjali piiritlemiseks valisime uurimisobjektiks kirjandusõpikud kui ühelt poolt kõige professionaalsemalt ja läbimõeldumalt teostatud, teisalt aga ühe suurima mõjuulatusega teosed.

${ }^{1}$ Täpsemaid strateegiaid vt nt Hermans 1988, kus nimetatakse neli peamist pärisnimede tõlkimisviisi, või Fernandes 2006, kus eristatakse neid koguni kümme. 


\section{Kreeka pärisnimed lätikeelsetes antiikkirjanduse õpikutes}

Lätis on antiiknimede edasiandmine keeruline probleem, mis muutub aktuaalseks iga kord, kui ilmub mõni selliseid nimesid sisaldav publikatsioon. Laias laastus võib läti keeles eristada kaht perioodi: okupatsioonieelne ja -järgne nimede esitamise situatsioon. Jossif Tronski „Antiikkirjanduse ajalugu” (1954) esindab nende kahe perioodi vahelist piiri, näidates selgelt suunda, mis valiti mitte üksnes antiikkultuuri vahendamiseks, vaid läti keele arenguks üldse. Tronski õpik on ühtlasi kõige suuremahulisem antiikkirjanduse ajalugu käsitlev publikatsioon läti keeles. Pärast Läti iseseisvumist on avaldatud küll antiikkirjanduse antoloogia, kuid ei ole ilmunud ühtegi uut antiikkirjanduse ajaloo õpikut.

Antiiknimede vahendamisega seotud küsimused tõusid Lätis päevakorrale juba seoses esimeste tõlgetega XIX sajandil ning sellel perioodil on nimedes näha nii vahenduskeelte mõju kui ka ilukirjandusliku läti keele kujunemisprotsessi jälgi. Nii on XX sajandi alguseks kujunenud ühest nimest mitu erinevat versiooni.

Enne Nõukogude Läti perioodi ilmus kaks mahukat antiikkirjanduse ajaloo käsitlust: Kārlis Straubergsi „Rooma kirjandus” 1936. aastal ning Pēteris Kiķauka „Kreeka kirjanduse ajalugu” 1944. aastal, samal ajal kui antiikkirjanduse enda vahendamine oli alanud juba XIX sajandi keskpaiku. Ka esimene iseseisvusaeg oli antiikkirjanduse populariseerimise ja uurimise seisukohalt tähtis - siis valmistati ette esimesed filoloogilised tõlked ja avaldati rida kommenteeritud tõlkekogumikke (Straubergs 1922; Horatius 1924-1936; Homeros 1943 jne). Ilmus suurel hulgal antiikkirjanduse tõlkeid, nagu ka artikleid antiikkirjandusest, -kultuurist ja -ajaloost.

Mõlema esimesel iseseisvusperioodil avaldatud antiikkirjanduse ajaloo raamatu autoril on näha taotlust vahendada kreeka ja ladina nimesid võimalikult klassikalise hääldusega kooskõlas (sama saab öelda ka terminite kohta). Sellegipoolest ei ole nende õpikute põhjal formuleerunud rangeid ja ühemõttelisi nimede vahendamise põhimõtteid. Seda on eriti näha kreeka nimede puhul, kus ebajärjepidevuse tingivad küsimused, mille üle vaieldakse siiamaani: nt kas kreeka rõhk peaks olema läti keeles edasi antud pika vokaaliga, kuidas anda edasi spiritus asper'it ehk tugevat hõngust ning aspireeritud konsonante jne. Teisalt aga tulid akadeemilise diskussiooni kõrval igapäevakasutusse ka need versioonid, mille lõid poeetiliste vormide tõlkijad ja vahendajad. Enne 1944. aastat valitsenud olukorra tunnuseks ongi versioonide paljusus: samaaegselt eksisteerisid erinevad nii kreeka kui ka ladina nimede vahendamise põhimõtted. Ebasüsteemsusele antiiknimede vahendamises pöörasid tähelepanu ka lingvistid ning avaldati rida publikatsioone ja poleemikat teaduslikes ning populaarteaduslikes väljaannetes (nt Garais 1930; Plāḳis 1929; Felsbergs $1922 \mathrm{jt})$.

Olukord muutus koos poliitilise situatsiooniga. Nii nagu teisteski eluvaldkondades, hakati ka keeles elimineerima mitmekesisust ning lähenemiste paljusust, seda on eriti näha 1950. aastate algul avaldatud raamatutes, sh 1951 ja 1952 ilmunud kaheköitelises antiikirjanduse antoloogias, Jossif Tronski „Antiikkirjanduse ajaloo" tõlkes (1954) ning ladina-läti sõnastikus (Latinuulatviešu vārdnīca 1955), mis on mahukaim ladina pärisnimede lätindamise allikas. Pärisnimede vahendamise põhimõtted alluvad vene keele põhi- 
mõtetele: pikki vokaale nimedes ja terminites ei kasutata. Järgnev võrdlus ilmestab pärisnimede ortograafiapõhimõtete muutumist:

\begin{tabular}{|c|c|c|}
\hline kreeka / ladina & Kikauka 1944 & Tronski 1954 \\
\hline Aivcías / Aenēās & Ainejs & Enejs \\
\hline A $\chi 1 \lambda \lambda \varepsilon v ́ \varsigma /$ Achilleus & Achillejs & Achiless \\
\hline 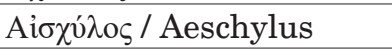 & Aischils & Eschils \\
\hline Atīas / Aiāx & Aiants & Ajakss (Ajants) \\
\hline 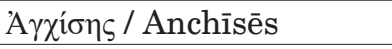 & Anchīss & Anchizs \\
\hline Eủpī & Eurīpids & Eiripids \\
\hline 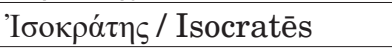 & Isokrats & Izokrats \\
\hline 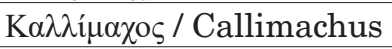 & Kallimachs & Kalimachs \\
\hline$\Lambda \bar{v} \sigma^{\prime} \bar{\alpha}_{\varsigma} / \mathrm{Ly} s i a ̄ s$ & Līsijs & Lizijs \\
\hline 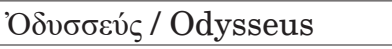 & Odisejs & Odisejs \\
\hline Oidínovৎ / Oedipūs & Oidips & Edips \\
\hline 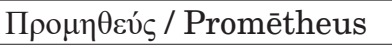 & Promētejs & Prometejs \\
\hline$\Sigma \alpha \pi \varphi \omega ́$ / Sapphō & Sapfoja & Sapfo \\
\hline 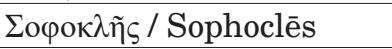 & Sofokls & Sofokls \\
\hline
\end{tabular}

Tronski nimekasutus erineb varasemate raamatute omast: nii diftongid kui ka geminaadid on lihtsustunud, intervokaalne $s$ on asendunud $z$-ga, ka pikki vokaale tähistavad makronid on ära jäetud. Iseloomulik on, et antiikteoste pealkirjad tõlgiti läti keelde - võimalik, et mõjutajaks on see, et originaalis anti teoste pealkirjad edasi vene keelde tõlgituna. Nende mahukate materjalide kaudu (kirjanduse ajalugu, antoloogiad ja sõnastikud) kehtestas uus võim ka uued lähenemissuunad keele uurimisele ja juhised kultuuripärandi tõlgendamiseks.

Ehkki need väljaanded demonstreerisid uusi suundi, ei ole neis pärisnimede vahendamise põhimõtted siiski selgelt formuleeritud ning nii mõnigi uuendus jääb traditsioonis omaks võtmata. 1959. aastal tulid Nikolai Kuni „Vanakreeka legendide ja müütide” tõlkes taas kasutusele makronid, ehkki mitte igal pool ja läbivalt.

Hilisemate nõukogudeaegsete publikatsioonidega, nagu Lija Čerfasa ja Tamāra Fomina „Antiikkirjanduse ajalugu” (1968), saab alguse uus omapärane „traditsioon” - pärisnimede ja antiikpäritolu sõnakujude muutmine juba avaldatud tõlgete uusväljaannetes. See kirjandusloo raamat järgib strukturaalselt ja sisuliselt Tronski õpiku eeskuju, osalt koguni otseste tsitaatidega ja samu näiteid kasutades, kuid nimed esitatakse teisel kujul.

Pärast Läti iseseisvuse taastamist avaldati uued kreeka ja rooma kirjanduse antoloogiad (1990 ja 1994). Antoloogiate struktuur sarnaneb 1950. aastate antoloogiaga, kuid pärisnimede kasutus lähtub uutest põhimõtetest ning varem avaldatud tõlgete taasesituses on pärisnimed korrigeeritud. Samuti on tänapäeva läti keele standardite järgi parandatud Nikolai Kuni müüdiraamatu uustrüki (2016) keelt, sealhulgas ka pärisnimede ortograafiat.

Kreeka ja ladina päritoluga pärisnimede vahendamise küsimus on läti humanitaarias pidevalt aktuaalne. Pärast taasiseseisvumist ja klassikalise filoloogia taastamist Läti ülikoolis on avaldatud ka mitmeid selleteemalisi publikatsioone (nt Vecvagars 2008; Rūmniece 2009; Laizāns, Lāms 2014). 
Tänase päevani ei ole pärisnimede ortograafiaküsimusel järjekindlat ega püsivat lahendust. Ortograafiareeglite kohaselt tuleks võõrnimesid läti keeles esitada nende algupärast hääldust järgides ning kooskõlas läti alfabeedi ja foneetilise süsteemiga, ehkki tüvedele lisatakse lätipärased lõpud. Kuid et puuduvad kindlad normid nendeks puhkudeks, kui võõrnimes on läti keeles puuduvaid häälikuid või kui traditsioonis on kinnistunud erinevad paralleelsed variandid (nt Oidipus on Oidips Sophoklese draama puhul, aga Edips Freudil ja Tronski õpiku tõlkes), on siiani käibel kaks erinevat lähenemist: esimene nendest on traditsioonile orienteeritud, teine aga püüab järgida kreeka ja ladina originaale.

Kokkuvõttes on iga ajajärgu antiikkirjanduse väljaannetes vähemalt üritatud esitada teaduslikult põhjendatud, reguleeritud ja ühtseid põhimõtteid, ent niipea kui avaldatakse uusi materjale, on senised printsiibid oma aktuaalsuse kaotanud. Ehkki antiikkirjanduse õpikud peaksid olema pärisnimede vahendamise osas kõige usaldusväärsemad allikad, ei ole see alati nii, nagu demonstreerib peagi pärast Tronski õpikut ilmunud Nikolai Kuni teose lätikeelne tõlge.

On üsna vähe tõenäoline, et Lätis avaldatakse lähiajal uus antiikkirjanduse ajalugu käsitlev raamat, kuid Läti rahvusraamatukogu kureerimisel koostatakse parasjagu uut rahvusentsüklopeediat Läti Vabariigi 100. aastapäeva auks ning plaanide kohaselt lülitatakse sellesse ka antiikmaailma käsitlevad artiklid. Nende artiklite autorite ees on uus väljakutse: kuidas vahendada antiiknimesid? Kuidas anda edasi antiikkirjanduse termineid? Kuidas luua ja kommenteerida läti keeles kättesaadavate allikate bibliograafiat?

\section{Kreeka pärisnimed leedu keeles: Jossif Tronski „Antiikkirjanduse ajalugu" kahe traditsiooni vahel}

Antiiknimede leedundamise probleem on samuti olnud pidevalt päevakorral ning pole veel täielikku lahendust leidnud. See avaldub nii nimekujude varieerumises kui ka meedias jätkuvates arutlustes.

Vanakreeka ja ladina pärisnimede vahendamise ajalugu leedu keeles saab jälgida juba alates varaseimatest kirjutistest XVI sajandist. Nende materjalide põhjal on lihtne järeldada, et XVI-XVIII sajandil on antiiknimede kasutus ja transkriptsioon sporaadiline, ilma mingite reeglite või süsteemita. Mõnikord kasutatakse rahvalikku kõnekeelt, st nimed kohandatakse leedu murrete reeglitele. Teistel juhtudel on nad mõjutatud poola keelest, kuid on ka lihtsalt algupäraseid ladina vorme, millele on lisatud leedupärane lõpp. Ainus selge tendents, mis on varastes leedukeelsetes kirjutistes jälgitav ning säilitatud ka tänapäevases kasutuses, on ladina nimede kirjutamine keskaegse häälduse reeglite kohaselt.

Esimesed teadlikud katsed antiiknimede leedu keeles esitamist korrastada tehti XIX sajandi lõpus ja eriti XX sajandi alguses. See oli aeg, kui Leedu rahvuslik liikumine viis esimese iseseisvumiseni, kui ladina tähestiku trükikeeld 1904. aastal tühistati ja kultuurielu muutus kõigis oma vormides aktiivsemaks. Esimesel iseseisvusajal enne Teist maailmasõda asutati Kaunase ülikool, mis jätkas klassikalise filoloogia traditsiooni Leedus, kirjutati või tõlgiti kooli- ja kõrgkooliõpikuid, Kaunase ülikooli professorid avaldasid monograa- 
fiaid kreeka kirjandusest ja kunstiajaloost. Ajakirjanduses arutleti aktiivselt antiiknimede leedundamise üle. 1920. ja 1930. aastatel ilmusid esimesed fundamentaalsed tõlked, mille autoriks olid nii klassikalistest filoloogidest õpetlased kui ka mitteprofessionaalid, kes valdasid suurepäraselt antiikkeeli tänu klassikalisele gümnaasiumiharidusele, ning avaldati terve rida olulisi antiiktekste, aga ka ladina-leedu sõnastik.

Saab üsna kindlalt väita, et sellel perioodil kujunesid välja rohkem või vähem selgepiirilised kreeka nimede leedundamise tendentsid. Võime oletada, et kui sellel traditsioonil oleks olnud võimalik edasi kujuneda, oleks sellest saanud standardne praktika. Siin on peamised kreeka nimede leedundamise põhimõtted:

1) 3. käändkonna kreeka nimisõnad transkribeeritakse leedu keelde geni-

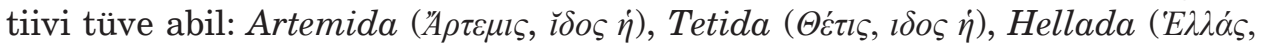
$\dot{\alpha} \delta o \varsigma \dot{\eta})$ jne.

2) Kõik kreeka diftongid transkribeeritakse vastavate leedu diftongidega:

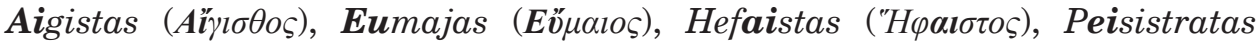

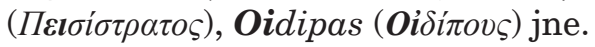

3) Kreeka $\sigma$ kahe vokaali vahel transkribeeritakse leedu $s$-iga: Aisonas

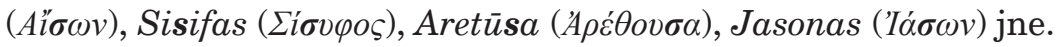

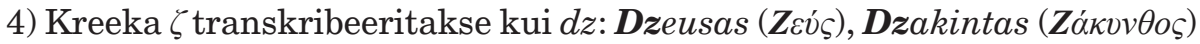
jne.

5) Kreeka $\kappa$ transkribeeritakse kõigis positsioonides $k$-na: Kirke $(\boldsymbol{K} i \rho \kappa \eta)$,

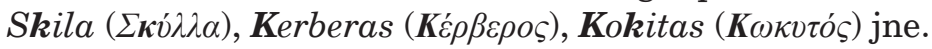

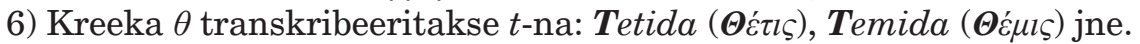

7) Kreeka geminaadid transkribeeritakse kaksikkonsonantidena: Odis-

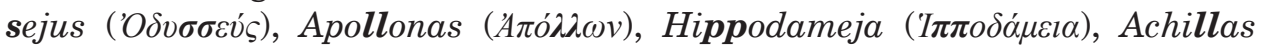

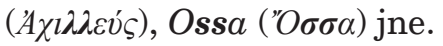

Teise maailmasõja järel aga olukord muutus. Osa professoreid ja tõlkijaid emigreerus läände, osa saadeti Nõukogude vangilaagritesse. Leetu jäänud õppejõud kolisid koos klassikalise filoloogia osakonnaga pärast 1940. aastal toimunud leedukeelse Vilniuse ülikooli taasavamist Vilniusse.

On huvitav vaadata, kuidas ja millal algab Nõukogude ühtluspoliitika ja vene keele mõju antiiknimede leedukeelsele kasutusele. Ühelt poolt jätkusid juba nimetatud tendentsid Nõukogude okupatsiooni teise ja isegi kolmanda kümnendini, ja seda eriti antiikautorite tõlgetes. ${ }^{2}$ Teisalt aga mõjutas uusi venekeelsete teoste tõlkeid, nagu näiteks antiikajaloo õpikud (Mišulinas 1946; Sergejevas 1952), olulisel määral vene keel, mille tulemusel kalduti varasematest kreeka pärisnimede vahendamise põhimõtetest kõrvale.

Murrangut tähistab Jossif Tronski „Antiikkirjanduse ajaloo” tõlkimine leedu keelde ja selle mitmes trükis avaldamine okupatsiooni alguskümnenditel. Tronski õpikust sai peamine kreeka ja ladina kirjanduse õppevahend kõrgkoolides kuni 1998. aastani, mil ilmus Dalia Dilytè kirjutatud antiikkirjanduse õpik (kordustrükid 1999 ja 2005). Tronski õpiku leedukeelse variandi 1951. ja 1961. aasta väljaannete võrdluses (ilmus ka vahepealne, 1955. aasta trükk) tulevad muutused põhimõtetes selgelt esile:

${ }^{2}$ Nt Aischylose „Aheldatud Prometheus” (1947); uus Homerose „Odüsseia” väljaanne (1948) järgib varasemat versiooni (1937). 
1. Kreeka diftongid $\alpha_{l}$ ja ol transkriptsioon on $a i$ ja oi esimeses trükis ning venepärane $e$ teises trükis.

\begin{tabular}{|c|c|c|}
\hline kreeka / ladina & Tronski 1951 & Tronski 1961 \\
\hline Aï $\gamma 1 \sigma \theta$ os / Aegisthus & Aigistas & Egistas \\
\hline 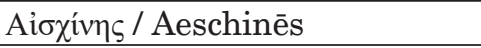 & Aischinas & Eschinas \\
\hline 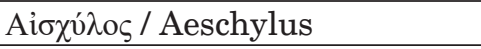 & Aischilas & Eschilas \\
\hline 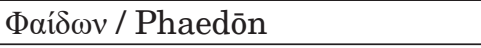 & Faidonas & Fedonas \\
\hline 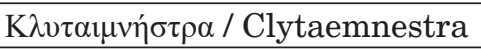 & Klitaimnestra & Klitemnestra \\
\hline Kроі̃бos / Croesus & Kroisas & Krezas \\
\hline Oífímovs / Oedipūs & Oidipas & Edipas \\
\hline Фоїßos / Phoebus & Foibas & Febas \\
\hline
\end{tabular}

2. Geminaadid kaovad nii ladina kui ka kreekakeelsete nimede leedu variantidest.

\begin{tabular}{|c|c|c|}
\hline kreeka/ladina & \begin{tabular}{|l|} 
Tronski 1951 \\
\end{tabular} & \begin{tabular}{|l|} 
Tronski 1961 \\
\end{tabular} \\
\hline Atta & Atta & Ata \\
\hline 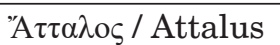 & Attalas & Atalas \\
\hline Cinna & Cinna & Cina \\
\hline Catullus & Katullas & Katulas \\
\hline Kópıvva / Corinna & Korinna & Korina \\
\hline Ennius & Ennijus & Enijus \\
\hline Gallus & Gallas & Galas \\
\hline Gellius & Gellijus & Gelijus \\
\hline
\end{tabular}

3. Esimeses Tronski väljaandes kirjutatakse silpidevahelise piiri selgemaks markeerimiseks kahe vokaali vahele $j$, teises väljaandes aga enam mitte.

\begin{tabular}{|c|c|c|}
\hline kreeka / ladina & Tronski 1951 & Tronski 1961 \\
\hline Fabiānus & Fabijanas & Fabianas \\
\hline 'I $\lambda_{\text {Iás / Ilias }}$ & Ilijada & Iliada \\
\hline "I $\lambda_{\text {1ov }} /$ İlion & Ilijonas & Ilionas \\
\hline 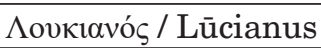 & Lukijanas & Lukianas \\
\hline Apí $\omega v$ / Arīōn & Arijonas & Arionas \\
\hline
\end{tabular}

4. Mõningatel juhtudel kirjutatakse keskaegse ladina häälduse mõjul kreeka sigma kahe vokaali vahel leedu versioonis $z$-iga. See tendents muutub nõukogude perioodi vältel veelgi tugevamaks.

\begin{tabular}{|c|c|c|}
\hline kreeka / ladina & Tronski 1951 & Tronski 1961 \\
\hline 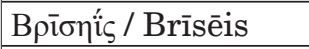 & Brizejidè & Brizeidè \\
\hline 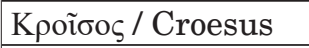 & Kroisas & Krezas \\
\hline 'Hoíodos / Hēsiodus & Heziodas & Heziodas \\
\hline$\Delta$ ióvv̄бos/Dionȳsus & Dionizas & Dionizas \\
\hline 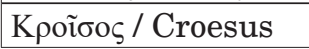 & Kroisas & Krezas \\
\hline
\end{tabular}

Tronski raamatu tõlgetest ei saanud kreeka ja ladina nimede leedu keelde vahendamisel siiski otsest eeskuju - nõue järgida venepärast kirjaviisi ei 
olnud tõlkijate vaba valik, vaid selle olid neile peale surunud õpiku toimetajad. Kuid sellegipoolest on just Tronski 1961. aasta väljaanne pärisnimede standardiseerimisel oluline tähis: lahkhelid toimetajatega ajendasid üht tõlkijatest, Jonas Dumčiust seda probleemi süvitsi analüüsima. Selle tulemusel kirjutas ta mahuka kaheköitelise (900 lk) väitekirja „Antiikaja pärisnimed leedu keeles" (Vilniuse ülikool, 1958). Dumčiuse uurimus käsitleb piibli- ja antiiknimede leedundamist alates kõige esimestest leedukeelsetest kirjutistest XVI sajandil kuni 1950. aastateni välja.

Pärast Leedu taasiseseisvumist võeti uuesti kasutusele mõningad kreeka nimede leedundamise põhimõtted, mis domineerisid enne nõukogude aega, sh kreeka diftongide $\alpha l$ ja ol transkribeerimine leedu diftongide $a i$ ja oi-ga. Samal ajal jäi ladina nimede vahendamine keskaegset traditsiooni järgides endiseks. Probleem tekib tavaliselt nendes raamatutes või antoloogiates, kus on koos nii kreeka kui ka ladina pärisnimed. Nii kirjutatakse sama nimi erinevalt, sõltuvalt sellest, kas ta on ladina või kreeka kontekstis, nt Faidra ja Aigistas Euripidesel ning Fedra ja Egistas Seneca teostes.

2015. aastal loodi digitaalne antiiksete pärisnimede andmebaas. ${ }^{3}$ Kreeka ja ladina pärisnimede koondamine ühte andmebaasi (ühtekokku u 12000 kirjet) annab üldisema pildi ja lubab luua nimede leedundamise kriteeriumid ning formuleerida üldised põhimõtted ja spetsiifilised reeglid, st võimalikuks saavad katsed välja arendada teoreetiline leedu transkriptsioonisüsteem. Teisalt on aga täiuslik süsteem vaevalt võimalik - igal reeglil on erandid, kui arvesse võtta ka eraldi nimekujude traditsioonilist esitamist. Andmebaasi peamiseks printsiibiks on säilitada kreeka ja ladina nimede foneetilised ning morfoloogilised parameetrid nii originaalilähedaselt kui võimalik, harmoneerides neid samal ajal leedu keele mudelitega ning kreeka ja ladina nimisõnadega tänapäevases leedu keeles.

\section{Kreeka nimed eestikeelsetes antiikkirjanduse õpikutes}

Antiiknimede eestindamise olukord ei ole unikaalne ning me näeme üsna olulisi ühisjooni naabritega. XIX sajandil ja XX sajandi esimesel poolel olid Eestis antiiknimede kirjakujud täiesti ühtlustamata. Vahel kasutati saksa kirjakujusid, vahel ka muid transkriptsioonipõhimõtteid; eriti suur ebajärjepidevus valitses kreeka konsonante $\chi, \theta, \varphi$ ja $\xi$ ning vokaali $v$ sisaldavate sõnade kirjaviisis. Samuti oli ebajärjepidevust diftongide $\alpha l$ ja $o l$ vahendamisel: esines nii diftonge kui ka $\ddot{a}$-d ja $\ddot{o}$-d. Ka nimede lõppudes on segadust: kord oli kasutusel kreekapärane -os, kord ladinapärane -us, aga vahel jäeti lõpp üldse ära. Ebajärjepidevust on ka vokaalipikkuste edasiandmisel: kord esitati pikk vokaal kahekordse vokaaliga, teinekord jälle pikkust kirjakujus ei kajastatud. Mida aga esines küllaltki vähe (eriti võrreldes meie naabritega), on nimekuju tuletamine genitiivsest tüvest - tavaliselt on nimekuju aluseks võetud siiski nominatiivne vorm.

Ent sellegipoolest hakkame juba 1920. aastatel märkama teatud korrastavaid tendentse, mida aitasid populariseerida ka kirjandusõpikud - neid avaldati esimesel iseseisvusajal õige mitu. 1926. aastal ilmus esimene osa Tadeusz

${ }^{3}$ Leedu Teadusagentuuri projekt „Antiikaja pärisnimede digitaalne andmebaas” kestis 2013-2015 ning selle teostajateks olid Vilniuse ülikooli teadlased. Andmebaas on kõigile kasutajatele vabalt kättesaadav: http://www.vardynas.flf.vu.lt/. 
Zieliński „Vana-kreeka kirjandusest”, järgmisel aastal kohe ka teine osa. Tõlkija Linda Metslang on pärisnimede eestindamisel lähtunud järgmistest reeglitest:

1) 3. käändkonna kreeka nimed transkribeeritakse eesti keelde nomina-

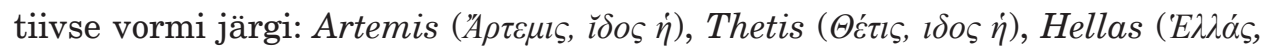
$\dot{\alpha} \delta o \varsigma \dot{\eta})$ jne.

2) Kõik kreeka diftongid transkribeeritakse vastavate eesti diftongidega:

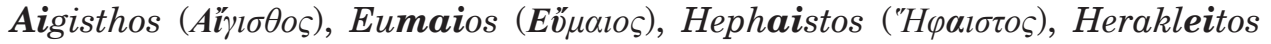

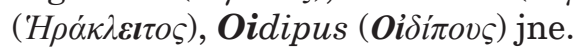

3) Kreeka $\zeta$ transkribeeritakse võõrtähe $z$ abil: Zeus (Zcv́s).

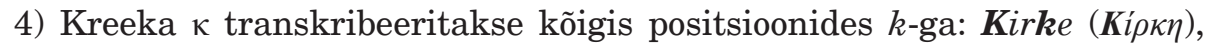

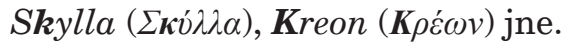

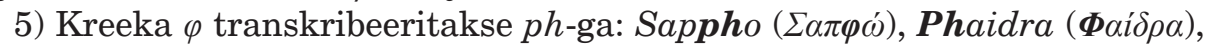

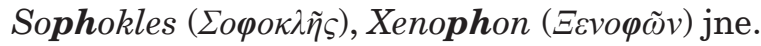

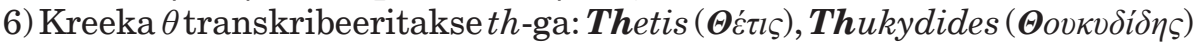
jne.

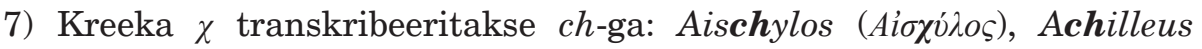

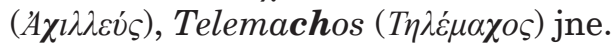

8) Kreeka geminaadid transkribeeritakse kaksikkonsonantidena: Odys-

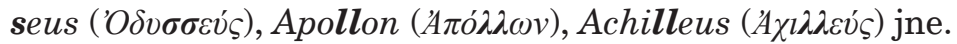

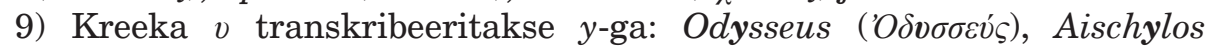

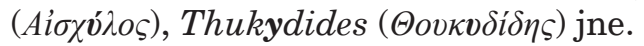

Teisalt on aga selgelt näha, kuidas isiku- ja kohanimede eestindamist käsitletakse eri põhimõtte kohaselt: kohanimedes lihtsustuvad $\theta$ ja $\varphi$ eestipärasteks aspireerimata konsonantideks (Teeba, Efesos), $y$ asemel aga kasutatakse eesti vokaali $\ddot{u}$ : Küreene, Siküoon. Konsonantühendiga antakse edasi

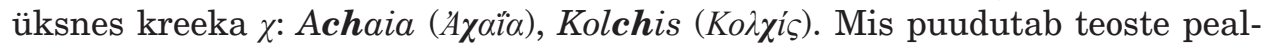
kirju, siis siin näeme teatud ebajärjepidevust: kohati transkribeeritakse neid sarnaselt pärisnimedega, kohati aga lihtsutatakse nagu kohanimesid. Võib öelda, et Metslangi põhimõtted lõid standardi: samasugustest reeglitest lähtus ka Ervin Roos, kes avaldas 1935. aastal oma „Ülevaate vana-kreeka kirjandusest"; erinevused ilmnevad vaid mõningates teoste pealkirjades, mida hakati käsitlema pärisnimedest erinevana ja lihtsustama kohanimede reeglite järgi: nii said „Odysseiast” „Odüsseia” ja „Trachiniaist” „Trahhiinlannad”, teisalt aga säilitasid võõrapärase kuju nt Aristophanese „Eirene” („Rahu”) ja „Thesmophoriazusai” („Naised tesmofooridel”, Metslangi vahendusel lihtsalt "Tesmoforiad").

1933. aastal ilmus Elmar Muugi „Väike õigekeelsus-sõnaraamat”, milles tehti katse antiiknimede eestindamist ühtlustada, ning ehkki kriitikud on hiljem juhtinud tähelepanu sellele, et mõningaid tema reegleid pole võimalik järjepidevalt järgida (vrd nt Nurm jt 1961: 554), oli tema kehtestatud normistikul siiski märgatav mõju eestiaegsele õppe- ja teatmekirjandusele.

Juba 1949. aastal, väga ruttu pärast Eesti okupeerimist, anti eesti keeles välja Jossif Tronski „Antiikkirjanduse ajalugu”, mille tõlkijaks oli Justa (Aita) Kurfeldt. Võrreldes eestiaegsete tavadega näeme tema transkriptsioonis teatud muutusi ning eelkõige puudutavad need $\varphi$ ja $v$ transkriptsiooni - esimest hakatakse ka pärisnimedes vahendama $f$-ga, teist aga $\ddot{u}$-ga: Sapfo ja Odüsseus. Kuna th ja ch antakse edasi varasemate põhimõtete järgi, võib siin rääkida teatud ebajärjepidevustest. Vrd nimede ortograafiat Zieliński ja Tronski kirjandusõpikutes: 


\begin{tabular}{|c|c|c|}
\hline kreeka / ladina & Zieliński 1926 & Tronski 1949 \\
\hline A $\chi \imath \lambda \lambda \varepsilon \varepsilon v \zeta$ / Achilleus & Achilleus & Achilleus \\
\hline 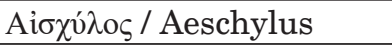 & Aischylos & Aischülos \\
\hline Aî̄ $\bar{\varsigma} / \operatorname{Aiāx}$ & Aias & Aias \\
\hline 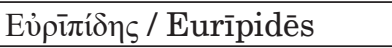 & Euripides & Euripides \\
\hline 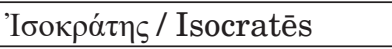 & Isokrates & Isokrates \\
\hline 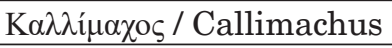 & Kallimachos & Kallimachos \\
\hline 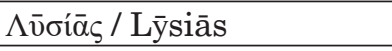 & Lysias & Lüsias \\
\hline 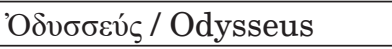 & Odysseus & Odüsseus \\
\hline 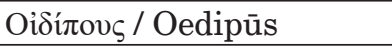 & Oidipus & Oidipus \\
\hline 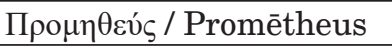 & Prometheus & Prometheus \\
\hline$\Sigma \alpha \pi \varphi \omega ́$ / Sapphō & Sappho & Sapfo \\
\hline 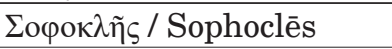 & Sophokles & Sofokles \\
\hline
\end{tabular}

Järgmises tabelis on aga näitlikustatud teoste pealkirjade vahendamist.

\begin{tabular}{|c|c|c|}
\hline kreeka & Zieliński 1926 & \begin{tabular}{|l|} 
Tronski 1949 \\
\end{tabular} \\
\hline Aï $\imath 1 \alpha$ & \begin{tabular}{|l|} 
Aitia \\
\end{tabular} & Põhjused \\
\hline A $\chi \alpha \rho v \varepsilon i \tilde{~}$ & Acharnalased & Ahharnlased \\
\hline 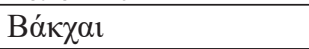 & Bakchid & Bakhandid \\
\hline 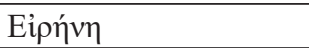 & Eirene & Rahu \\
\hline 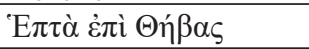 & Seitse Teeba vastu & Seitse Teebai vastu \\
\hline 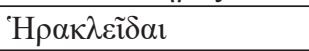 & \begin{tabular}{|l|} 
Herakleidai \\
\end{tabular} & Herakleidid \\
\hline 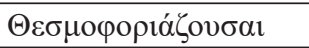 & Tesmoforiad & Naised tesmofooride pühal \\
\hline 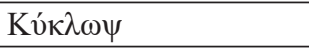 & Küklops & Kükloop \\
\hline 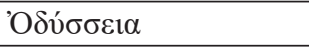 & Odysseia & Odüsseia \\
\hline 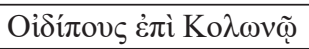 & Oidipus Koloonoses & Oidipus Koloonoses \\
\hline 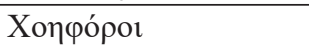 & Choefoorid & Choeforoi \\
\hline 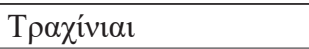 & Trachiniai & Trahhiinlannad \\
\hline
\end{tabular}

Siin valitseb veelgi suurem ebaühtlus kui pärisnimede puhul: kohati on Tronski tõlkes pealkirju kodustatud („Trahhiinlannad”) ja isegi tõlgitud („Põhjused”, „Rahu”), kohati on jälle võõrapärastatud („Choephoroi”). Samuti on ebajärjepidevused transkriptsioonis (vrd „Ahharnlased” vs. „Choeforoi”).

Õige pea pärast Tronski õpiku ilmumist tõusis seoses „Suure õigekeelsussõnaraamatu" koostamisega jälle päevakorrale antiiknimede ortograafia küsimus. Sellega hakkas tegelema Keele ja Kirjanduse Instituudi sõnaraamatute ja õigekeelsuse sektor, mida juhtis Johannes Veski, kuid eriti oluline oli samas sektoris töötanud Ernst Nurme panus, kes töötas välja konkreetsed juhised antiiknimede vahendamiseks. Need tekitasid elavat vastukaja ja 1950. aastate lõpul toimusid nimede kirjakuju üle ägedad diskussioonid.

Kujunes kaks vastaspoolt, mille ühe poole eestkõneleja oli Ernst Nurm, teise poole seisukohti esindasid Ain Kaalep ja Johannes Veski. Nurm avaldas Keele ja Kirjanduse Instituudi 1958. aasta kogumikus kreeka pärisnimede eestindamisele pühendatud artikli, mille peamine sõnum oli, et kreeka nimed tuleks delatiniseerida, eelkõige pidades silmas seda, et $\xi$ tuleks $x$-i asemel läbivalt transkribeerida $k s$-iga, $\varphi$ ph asemel $f$-ga, $\chi c h$ asemel $h h$-ga, $\theta$ th asemel ja $\dot{\rho} r h$ 
asemel vastavalt $t$ ja $h$-ga, $v$ aga $y$ asemel $\ddot{u}$-ga, st tuua ka pärisnimedesse läbivalt põhimõtted, mida kasutati varasemas traditsioonis kohanimedes ja pealkirjades ja mida Kurfeldt oma Tronski tõlkes kasutas juba $\varphi$ ja $v$ transkriptsioonis.

Kaalep ja Veski võtsid aga selle vastu sõna nii spetsiaalsetel diskussioonikoosolekutel kui ka artiklites. Veski (1961) heitis Nurmele ette kõigepealt järjekindluse puudumist ( $\xi$ on ainult kohati $k s$-iga transkribeeritud), aga esitas ka lingvistilisi põhjendusi, miks ta Nurme soovitatud kirjaviisi sobivaks ei pea. Kaalep (1961) heitis samuti Nurmele ette segaduse külvamist; mis aga puudutab kreeka nimede ortograafiat, siis tema sõnul oli ladina transkriptsiooni kasutamine igati õigustatud, kuna kreeka ja ladina keel ongi omavahel erakordselt seotud ning ka kreeklased ise transkribeerisid oma keelt ladina tähestikku samamoodi. Lisaks sellele tõi ta teisigi pragmaatilisi ja lingvistilisi argumente, miks tuleks eelistada latiniseeritud nimekujusid.

Võib öelda, et mõnda aega pärast seda näemegi paralleelselt kahe erineva transkriptsioonisüsteemi kasutust. Juba 1960. aastal ilmunud „Iliase” ja 1963. aastal ilmunud „Odüsseia” tõlge populariseerisid endisaegset latiniseeritud nimekujude kasutust. Teisalt jälle näeme ajakirjanduses ilmunud artiklites korduvalt just Nurme soovitatud nimekujusid. 1966. aastal arutas vabariiklik õigekeelsuskomisjon kreeka pärisnimede transkribeerimist, ent kumbki ettepandud süsteem ei saanud vajalikku häälteenamust (Raiet 1966: 178).

Lõpuks on jäänud ülekaalukalt käibele siiski kahe maailmasõja vahelisel ajal välja kujunenud standardid ja seda ennekõike nende pooldajate viljaka publitseerimistegevuse tõttu, mis aitas vastavaid transkriptsioonireegleid populariseerida. Esiteks võiks siin nimetada 1960. aastatel alanud suurt Eesti Nõukogude Entsüklopeedia projekti, mille kirjandusartiklite eestvedajate sekka kuulusid ka Ain Kaalep ja Richard Kleis, teiseks antiikkirjanduse antoloogiaid (1964. aastal avaldati kreeka kirjanduse ja 1971. aastal rooma kirjanduse antoloogia) ning kolmandaks ehk isegi kõige tähtsamana Richard Kleisi koostatud õppematerjale, mis laialt populariseerisid vastavaid nimekujusid kõrghariduses.

Nimelt ilmus 1964. aastal üle pika aja esimene antiikkirjanduse originaalõpik: Richard Kleisi „Vana-Kreeka kirjanduse põhijooni” (kordustrükid 1965, 1968, 1974). Selle nimekujudes ei ole järgitud Nurme soovitusi ning kui võrdleme uuesti samade nimede kirjaviisi, võib järeldada, et Kleis on siin täielikult naasnud eestiaegse kirjaviisi juurde:

\begin{tabular}{|c|c|c|}
\hline kreeka / ladina & Zieliński 1926 & Kleis 1964 \\
\hline A $\chi \imath \lambda \lambda \varepsilon v ́ \varsigma /$ Achilleus & Achilleus & Achilleus \\
\hline 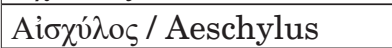 & Aischylos & Aischylos \\
\hline Aỉōs / Aiāx & Aias & Aias \\
\hline 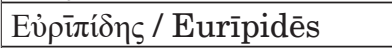 & Euripides & Euripides \\
\hline 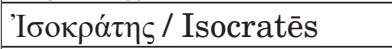 & Isokrates & Isokrates \\
\hline 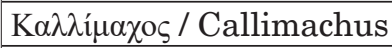 & Kallimachos & Kallimachos \\
\hline$\Lambda \bar{v} \sigma^{\prime}{ }^{\prime} \bar{\zeta} /$ Lȳsiās & Lysias & Lysias \\
\hline 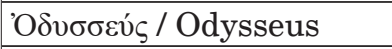 & Odysseus & Odysseus \\
\hline Oíínovৎ / Oedipūs & Oidipus & Oidipus \\
\hline 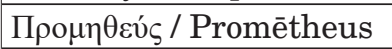 & Prometheus & Prometheus \\
\hline$\Sigma \alpha \pi \varphi \omega ́$ / Sapphō & Sappho & Sappho \\
\hline 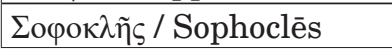 & Sophokles & Sophokles \\
\hline
\end{tabular}


Küll aga on toimunud olulisi muutusi teoste pealkirjade vahendamises:

\begin{tabular}{|c|c|c|}
\hline kreeka & Zieliński 1926 & Kleis 1964 \\
\hline Aḯı & Aitia & Põhjused \\
\hline 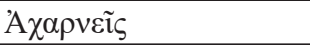 & Acharnalased & Ahharnlased \\
\hline Eịṕnvn & Eirene & Rahu \\
\hline 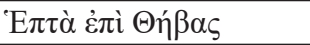 & Seitse Teeba vastu & Seitse Teeba vastu \\
\hline 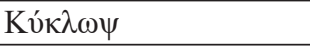 & Küklops & Kükloop \\
\hline 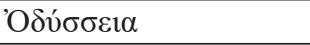 & Odysseia & Odüsseia \\
\hline 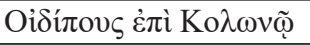 & Oidipus Koloonoses & Oidipus Kolonoses \\
\hline Хопфо́рог & Choefoorid & Hoefoorid \\
\hline 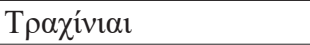 & Trachiniai & Trahhislannad \\
\hline
\end{tabular}

Kleis lähtus siin kodustavatest põhimõtetest, millele toetus ka Aita Kurfeldt, kuid viis need ellu süsteemselt ja järjepidevalt: nii on ka "Choephoroist” saanud „Hoefoorid”, „Trahhiinlannade” asemel on aga täpsem „Trahhislannad". Samal ajal on Kleis täiesti loobunud varasemate autorite ebajärjepidevast taotlusest kreeka vokaalipikkusi eesti keeles edasi anda: nt Trooja nimekujuga järgib ta 1960. aastateks väljakujunenud traditsiooni, kuigi originaalis on seal lühike $o$, Sophoklese tragöödia „Oidipus Kolonoses” aga esitab läbivalt lühikeste vokaalidega, kuigi originaalis on teine $o$ pikk.

Kleisi põhimõtted võib kokku võtta järgmiselt: pärisnimedes on kasutatud latiniseeritud transkriptsiooni, kasutades vajadusel võõrtähti, ent morfoloogilised lõpud on siiski kreekapärased (nt -os või -on). Pealkirjades ja kohanimedes aga eelistatakse eestipärast kirjaviisi. 1980. aastal avaldab Kleis juba antiikkirjanduse ajaloo õpiku ning sealgi on kinni peetud samadest põhimõtetest.

Need kirjakujud on püsinud üsna jõudsalt tänapäevani välja, ehkki vahel näeme teatud tendentsi latinisatsiooni levikuks ka pealkirjadesse, nt „Odüsseia” asemel näeme mõnikord kirjakuju „Odysseia” (vrd nt Tartu Uue Teatri lavastuse pealkirja). Kuid praegu on Tartu Ülikooli Kirjastuses töös tõlge Oliver Taplini „Kirjandusest Kreeka-Rooma maailmas” ning selles on kõik nimekujud esitatud täpselt sellisena, nagu Ain Kaalep ja Richard Kleis neid populariseerisid.

Kadri Novikovi eestvedamisel on TÜ klassikalistel filoloogidel käsil internetipõhise antiiknimede sõnastiku koostamine. ${ }^{4}$ Sõnastiku eesmärk on esitada antiikmaailma isiku- ja topograafiliste nimede soovitatavad eestipärased nimevormid, lisaks nimede paralleelvormid erinevates teatmeteostes ning tõlgetes. Sõnastikus kajastuvad nii nimede kreeka ja/või ladinakeelsed kui ka inglise-, prantsuse-, saksa- ja venekeelsed kujud. Sõnastik võiks olla abiks nimekujude esitamise süsteemsuse ja korrektsuse seisukohalt nt tõlkijatele, toimetajatele, üliõpilastele, aidates puhastada meie emakeelt võõrmõjudest. Sõnastikus on edaspidi plaanis esitada nimeversioonid ka tõlkijate kaupa, luues võimaluse võrrelda nimede kasutamise põhimõtteid ajaperioodide ja tõlkijate/autorite kaupa: selline ressurss on kasulik ka keele- ja tõlkeuurijatele.

\footnotetext{
${ }^{4}$ Baasfinantseerimise projekt nr PHVLC16933.
} 


\section{Kokkuvõte}

Kolme Baltimaa antiiksete pärisnimede ortograafia ajaloos ilmnevad sarnased arengumustrid ning laias laastus võib selle periodiseerida järgmiselt:

1) mitmekesisuse periood, kui süsteemitult on kasutusel erinevad nimekujud;

2) esimesed standardiseerimiskatsed ning normide väljakujunemise algus;

3) nõukogude aeg, mil pannakse vabariigiaegsed standardid kahtluse alla ning esmajoones Tronski õpiku tõlgetest tõukudes areneb nende üle poleemika; sealjuures võib paralleelselt tulla kasutusele mitu erinevat süsteemi;

4) taasiseseisvumisele järgnenud aeg, kui hakatakse uuesti tähelepanu pöörama standarditele, kas vanu taaselustades või uusi luues.

Hoolimata ühisjoontest on Eesti traditsioonil siiski võrreldes Läti ja Leedu omaga teatud eripärasid. Iseloomulik on võõrapärastav lähenemine: nimesid ei tehta enda omadeks, antakse edasi ka morfoloogilised tunnused. Samuti õnnestus tõhusamalt vastu seista nimede venestamisele: nõukogude ajal on pigem olnud vaidlus selle üle, kui kaugele minna eestipärastamisega. Ka siin on oluline roll Tronski antiikkirjanduse õpikul, kus tehti esimene katse vähemalt osaliselt võõrtähtedest loobuda.

Kõigil kolmel Baltimaal on lõplik standardiseerimine alles ees. Ka eesti ja leedu keeles, kus on küll üldiselt antiiknimede transkriptsioonireeglid kehtestunud, jääb sellegipoolest lahendust ootama veel terve rida üksikküsimusi, mis puudutavad nt kreeka nimesid ladina kontekstis, teoste pealkirju, kohanimesid ning traditsiooni ja täpsuse dilemmat.

Artikli valmimist on toetanud Euroopa Liidu Regionaalarengu Fond (Eesti-uuringute Tippkeskus) ning see on seotud Eesti Haridus- ja Teadusministeeriumi uurimisprojektiga IUT20-1 „Eesti kirjandus võrdleva kirjandusuurimise paradigmas”. Uurimistööd toetas Leedu Teadusagentuur (projekt „Antiiksete pärisnimede digitaalne andmebaas", teema juht Audronè Kučinskienè).

\section{Kirjandus}

Antikās literatūras antolog̣ija I 1951. Koost Rūdolfs Egle. Rīga: Latvijas Valsts izdevniecība.

Antikās literatūras antolog̣ija II 1952. Koost Rūdolfs Egle. Rīga: Latvijas Valsts izdevniecība.

Aischylos $1947=$ Aischilas, Prikaltasis Prometejjas. Tlk Ričardas Mironas. Vilnius: Valstybinè grožinès literatūros leidykla.

Čerfasa, Lija, Fomina, Tamāra 1968. Antīkās literatūras vēsture. Rīga: Zvaigzne.

Dily tè, Dalia 1998. Antikinè literatūra. Vilnius: Jošara.

Dumčius, Jonas 1958. Antikiniai tikriniai vardai lietuvių kalboje. Disertacija filologijos mokslų kandidato laipsniui iqgyti. Vilnius [käsikiri].

Fels b e rg s, Ernests 1922. Grieḳu īpašvārdu pareizrakstība latviešu valodā. Rīga: Latvijas Universitātes izdevums.

Fernandes, Lincoln 2006. Translation of names in children's fantasy literature: Bringing young reader into play. https://www.researchgate.net/publication/237246131_Translation_of_Names_in_Children's_Fantasy_Literature Bringing_the_Young_Reader_into_Play_i (8. III 2017) 
Garais, Fricis 1930. Daži latviešu valodas jautājumi. Rīga: Autora izdevums.

Hermans, Theo 1988. On translating proper names, with reference to De Witte and Max Havelaar. - Modern Dutch Studies. Essays in Honour of Professor Peter King on the Occasion of his Retirement. Toim Michael J. Wintle. LondonAtlantic Highlands: The Athlone Press, lk 11-24.

Homeros 1937 = Homeras, Odisejja. Tlk J. Ralys. Toim Vladimiras Šilkarskis. Kaunas: Švietimo ministerijos KLK-jos leidinys.

Homeros 1943 = Homērs, Odiseja. Tlk Augusts G̦iezens. Rīga: Latviju grāmata.

Homeros 1948 = Homeras, Odisèja. Tlk Jeronimas Ralys. Vilnius: Valstybinè grožinès literatūros leidykla.

Horatius 1924-1936 = Horatius, Horātija dzejas. Tlk Kārlis Straubergs. Rīga: A. Gulbis.

Ka a le p, Ain 1961. „Keele ja Kirjanduse” ringküsitlusest. - Keel ja Kirjandus, nr 1, lk 41-46; nr 2, lk 109-115.

Ķi ķa u ka, Pēteris 1944. Grieḳu literātūras vēsture. Rīga: Universitātes apgāds.

Kleis, Richard 1964. Vana-Kreeka kirjanduse põhijooni. Tartu: Tartu Riiklik Ülikool.

Kleis, Richard 1980. Antiikkirjanduse ajalugu. Kõrgkooli õpik filoloogia erialadel. Tallinn: Valgus.

Kreeka kirjanduse antoloogia 1964. Tallinn: Eesti Riiklik Kirjastus.

Ku n 1959 = Nikolajs Kūns, Sengrieķu mīti un varoṇteikas. Rīga: Latvijas Valsts izdevniecība.

Ku n 2016 = Nikolajs Kūns, Sengrieķu mīti un varoṇteikas. Rīga: Jumava.

Laizāns, Mārtiňš, Lāms, Ojārs 2014. Sengrieḳu īpašvārdu atveide latviešu valodā: paražas vs. paraugs lingvistikas un poētikas aspektos. - Alīse Laua (1914-1994). In honorem. Toim Andra Kalnača, Ilze Lokmane, Inta Urbanoviča. Rīga: LU Akadēmiskais apgāds, lk 98-105.

Latiṇu-latviešu vārdnīca 1955. Koost Klāra Veitmane, Lija Čerfasa, Henriks Novackis, Aleksejs Apīnis. Rīga: Latvijas Valsts izdevniecība.

Mišulin a s, A. V. (koost) 1946. Senovès istorija. Kaunas: Valstybinè pedagoginès literatūros leidykla.

Nu r m, Ernst 1958. Kreeka pärisnimede edasiandmisest eesti keeles. - Keele ja Kirjanduse Instituudi uurimused II. Tallinn: Eesti Riiklik Kirjastus, lk 43-52.

Nurm, Ernst, Raiet, Erich, Kindlam, Magnus 1961. „Õigekeelsuse sõnaraamatu” arvustuste puhul. - Keel ja Kirjandus, nr 9, lk 553-565.

Plāḳis, Juris 1929. Svešvārdu izruna un rakstība latviešu valodā. - Izglītības ministrijas mēnešraksts 5 , lk 477-480.

R a i et, Erich 1966. Vabariikliku õigekeelsuse komisjoni otsuseid. - Keel ja Kirjandus, nr 3, lk 178.

Rooma kirjanduse antoloogia 1971. Koost Ain Kaalep, Ülo Torpats. Tallinn: Eesti Raamat.

Ro os, Ervin 1935. Ülevaade vana-kreeka kirjandusest. Tartu: Loodus.

R ūmniece, Ilze 2009. Par grieḳu īpašvārdiem un grēcismiem latviešu valodas vidē. - Antiquitas Viva 3. Rīga: LU Akadēmiskais apgāds, lk 147-156.

Sengrieḳu literatūras antolog̣ija 1990. Koost Tamāra Fomina. Rīga: Zvaigzne.

Senās Romas literatūras antoloǵija 1994. Koost Tamāra Fomina. Rīga: Zvaigzne.

Sergejevas, Vladimiras 1952. Senovès Graikijos istorija. Vilnius: Valstybinè politinès ir mokslinės literatūros leidykla.

S tr a u b e r g s , Kārlis (koost) 1922. Grieksu lirika. Rīga: Izglītības ministrijas izdevums. Stra u bergs, Kārlis 1936. Romiešu literātūra. Rīga: Valters un Rapa. 
Zieliński, Tadeusz 1926-1927. Vana-kreeka kirjandus. Tlk Linda Metslang. Tartu: Eesti Kirjanduse Selts.

Taplin, Oliver (toim), ilmumas. Kirjandus Kreeka-Rooma maailmas. Tlk Kersti Unt, Janika Päll. Tartu: Tartu Ülikooli Kirjastus.

Tr o n s ki, I. M. 1949. Antiikkirjanduse ajalugu. Tlk J. Kurfeldt, J. Semper. Tartu: Teaduslik Kirjandus.

Tronski 1951, 1961 = Josifas Tronskis, Antikinès literatūros istorija. Tlk L. Valkūnas, J. Dumčius. Vilnius: Valstybinè politinès ir mokslinės literatūros leidykla. Tronski 1954 = Josifs Tronskis, Antikās literaturas vēsture. Tlk A. Ābele. Rīga: Latvijas Valsts izdevniecība.

Vecvagars, Māris 2008. Sengriek̦u-latviešu īpašvārdu vārdnīca. Rīga: Filozofijas un socioloğijas institūts.

Veski, Johannes Voldemar 1961. Kreeka ja ladina sõnavara omavahelisest suhtumusest eesti keeles. - Keel ja Kirjandus, nr 1, lk 37-41.

\section{Greek proper names in ancient-literature textbooks on the example of Baltic countries}

Keywords: history of translation, proper names, ancient literature, domestication, foreignization

In studying the history of translation, it is important to pay attention not only to the focal questions such as who translated, what was translated, or how it was translated, but also to some narrower issues, such as for example the rendering of puns, culture-specific items, terms, and proper names. Proper names are often more than just simple carriers of orthographic norms: they can also be signs of an era, expressing the dominant tendencies in culture and/or ideology.

The purpose of this paper is to compare the history of rendering Greek proper names in three countries with a similar fate - Latvia, Lithuania and Estonia. In order to limit down the vast material, literature textbooks were chosen as the object of research, as these are professional and well thought out works having a considerable role in popularizing the name forms.

The study reveals that the history of orthography of ancient proper names in the three Baltic states reveals similar evolutionary patterns: (1) a period of diversity and lack of system; (2) the beginning of establishing the norms; (3) the Soviet period, when republican standards were questioned; 4) the period of regained independence, when the standards of rendering ancient proper names are again revised. The standardization is not yet complete in any of the three Baltic states; even if the general standards have been formulated, there is still a number of issues which are yet to be solved, such as for example Greek names in the Latin context, the titles of ancient works, place names, and dilemmas between accuracy and tradition.

Līva Bodniece (b. 1987), MA, Riga Stradiņš University, Guest Lecturer, liva.bodniece@lu.lv

Audronè Kučinskienè (b. 1964), PhD, Vilnius University, Department of Classical Philology, Associate Professor, audronekucinskiene@hotmail.com

Maria-Kristiina Lotman (b. 1974), PhD, University of Tartu, Department of Classical Studies, Associate Professor, maria.lotman@ut.ee 